\title{
Stonesia ghoguei, Peculiar Morphology of a New Cameroonian Species (Podostemaceae, Podostemoideae)
}

\author{
Evelin Pfeifer and Valentin Grob \\ Institut für Systematische Botanik, Universität Zürich, Zollikerstrasse 107, CH-8008 Zürich, \\ Switzerland
}

Mike Thiv

Herbarium STU, Staatliches Museum für Naturkunde, Rosenstein 1, D-70191 Stuttgart,
Germany

Rolf Rutishauser

Institut für Systematische Botanik, Universität Zürich, Zollikerstrasse 107, CH-8008 Zürich, Switzerland. Author for correspondence: rutishau@systbot.uzh.ch

Abstract. The traditional circumscription of the genus Stonesia G. Taylor (Podostemaceae, Podostemoideae) includes three species restricted to western tropical Africa. Here, a new species, S. ghoguei E. Pfeifer \& Rutishauser, is described, which represents the first Cameroonian member of the genus. There are another three Stonesia species restricted to western tropical Africa (Guinea and Sierra Leone). The genus Stonesia is characterized by capsule valves with five or seven ribs each, with the ribs nearest the sutures shorter and not reaching the ends of valves. This unique pattern is shared with the two Madagascan genera Endocaulos C. Cusset and Paleodicraeia C. Cusset. Molecular (matK) data indicate that this capsule pattern is homoplastic, occurring in Madagascar and (with Stonesia) in tropical Africa. Various characters of Stonesia (including $S$. ghoguei) are also found in other African podostemoids. These include flower buds inverted in the sac-like spathella; crustose roots or broad ribbons with exogenous root lobes (daughter roots); stems usually simple (rarely branched), up to $10(-40) \mathrm{cm}$ long; flowers arising primarily from endogenous buds inside the stem cortex in $S$. ghoguei and S. fascicularis G. Taylor; and leaves repeatedly forked into narrow segments, with epiphyllous flowers arising from the clefts of these forks in $S$. ghoguei and $S$. heterospathella G. Taylor. Unlike the western African Stonesia species, $S$. ghoguei has pollen mainly released in monads (not only dyads), one stamen per flower with two lateral tepals (not two stamens with three tepals), and unilocular ovaries (not bilocular ones).

Key words: Cameroon, cauliflory, endogenous floral buds, epiphyllous flowers, IUCN Red List,
Ledermanniella, Podostemaceae, Stonesia, structural diversity.

The Podostemaceae (river weeds) are mainly restricted to tropical rivers, waterfalls, and cataracts in regions with distinct seasonality, where they grow attached to rocks or other solid substrata without penetrating them. The vegetative plants are completely submerged in swiftly running water during the rainy season. Emergent flowers and fruits are formed when the water recedes during the dry season. The Podostemaceae are the largest group of strictly aquatic flowering plants (Cook, 1999). Most of the ca. 280 species and many of the 49 genera are endemic to small geographical areas such as a single river or a country (Ameka et al., 2003; Cook \& Rutishauser, 2007). They show three main centers of biodiversity: Latin America, tropical Africa, and South to Southeast Asia (Engler, 1928; Cusset, 1987; Kato, 2006). There are 16 genera and ca. 85 species known from Africa and Madagascar; except for Tristicha Thouars, all of them are endemic to Africa and/or Madagascar. Eight of the 15 endemic genera occur with just one species in Africa or Madagascar. Most genera, including Stonesia, consist of six or fewer species. Ledermanniella Engler (as defined by Cusset, 1974, 1983, 1984) is the only species-rich exception in Africa, containing ca. 46 species. This genus, however, seems to be artificial, because-based on molecular and morphological evidence-various small African genera of Podostemoideae are nested in it. According to Moline et al. (2007), all podostemoids studied from Continental Africa form a clade that is sister to the Madagascan genera Endocaulos C. Cusset and Thelethylax C. 
Cusset. The reader will find identification keys, drawings, and short descriptions of all African and Madagascan taxa on the website: <http://www.systbot. uzh.ch/podostemaceae> (Rutishauser et al., 2007).

Stonesia as a new podostemoid genus was described by Taylor (1953). There have been three Stonesia species described; these are confined to a small region in Guinea and Sierra Leone, western tropical Africa (Cusset, 1973; Lebrun \& Stork, 1991; Cook \& Rutishauser, 2007). The genus Stonesia as known until now was distinguishable by the combination of three unique characters: (1) the number of capsule ribs varies from 12 to 18 (i.e., there are five to seven ribs per valve plus the sutures, usually marked by twin ribs that disappear after dehiscence); (2) the ribs nearest to the sutures do not run the whole capsule length but begin on the suture above the base and, curving parallel to the other ribs, rejoin it below the apex; and (3) flowers show two stamens on a common foot (andropodium) and three subulate tepals, one tepal on each side of the andropodium, and the third tepal in the fork between the filaments.

We studied recently collected accessions from Cameroon, which represent a new species attributed to Stonesia.

\section{MATERIALS AND METHODS}

The plant specimens used in the present study were fixed and preserved in $70 \%$ ethyl alcohol. The wet plant material is deposited in the National Herbarium of Cameroon (YA) and the Herbarium of Zurich Universities (Z/ZT). For scanning electron microscopy, the dissected plant parts were critical point dried and sputter-coated with gold. The electron micrographs were taken with a JEOL scanning electron microscope (JEOL, Ltd., Tokyo) at $20 \mathrm{kV}$. For microtome sections, specimens were embedded in Kulzer's Technovit 7100 (2-hydroethyl methacrylate; Heraeus Kulzer GmbH, Wehrheim, Germany) and sectioned with a MICROM HM 355 rotary microtome (GMI, Inc., Ramsey, Minnesota, U.S.A.) and conventional microtome knife types C and D. The mostly $7 \mu \mathrm{m}$ thick sections were stained with ruthenium red and toluidine blue.

To test possible relationships of Stonesia ghoguei to African and non-African taxa, we conducted a phylogenetic analysis based on mat $K$ sequence data. A modified data set by Moline et al. (2007) (tree base M2581) was used. Of these taxa, Cladopus japonicus Imamura (selected outgroup = OG), Dicraeanthus africanus Engler, Dj̈inga felicis C. Cusset (accessions 1 and 2), Endocaulos mangorense (Perrier) C. Cusset, Hydrobryum japonicum Imamura (OG), Ledermanniella bifurcata (Engler) C. Cusset, L. cf. bosii C.
Cusset, L. bowlingii (J. B. Hall) C. Cusset, L. ledermannii (Engler) C. Cusset (accessions 1 and 2), L. letouzeyi C. Cusset, L. linearifolia Engler, Podostemum ceratophyllum Michaux (OG), Polypleurum stylosum (Wight) J. B. Hall (OG), Thelethylax minutiflora (Tulasne) C. Cusset, and Zeylanidium olivaceum Engler (OG) were included, and $S$. ghoguei (from the type Ghogue GHO 1665; GenBank Acc. No. AM937251) was added. A maximum likelihood (ML, Felsenstein, 1981) analysis was performed using PAUP 4.0 (Swofford, 1998). To determine the nucleotide substitution model that best fits the data, the hierarchical likelihood ratio test was used in Modeltest 3.0 (Posada \& Crandall, 1998). ML analyses specifying the TVM $+\mathrm{G}$ model were implemented as heuristic searches with a 100 random-addition-sequence, tree bisection-reconnection, and steepest descent options. The same options were used for ML bootstrap analyses (100 replicates).

\section{RESULTS}

Stonesia ghoguei E. Pfeifer \& Rutishauser, sp. nov. TYPE: Cameroon. Adamawa: Ngaoundéré, Tello Waterfalls, $1100 \mathrm{~m}, 07^{\circ} 14^{\prime} 00^{\prime \prime} \mathrm{N}, 13^{\circ} 57^{\prime} 00^{\prime} \mathrm{E}, 16$ Feb. 2005, J.-P. Ghogue GHO 1665 (holotype, YA; isotypes, K, Z). Figures 1-5, 6A-G, I-M.

Haec species a congeneris tepalis lateralibus duobus, stamine in quoque flore solitario, ovario uniloculari atque polline plerumque in monadis liberato distinguitur.

Caulescent herb, attached to rocks; roots (thallus) dorsiventrally flattened, ribbon-like, more rarely crustose, root cap lacking, root with exogenous daughter roots or lobes; vegetative stems and reproductive short shoots arising from endogenous buds inside root, arranged along root margin, or in cleft of lobed root; vegetative stems to $10 \mathrm{~cm}$, simple, giving rise to leaves on one side (due to dorsiventral distichy). Foliage leaves with repeatedly forked segments, to $8.5 \mathrm{~cm}$, distal segments linear, slightly flattened and when young provided with hairs on one side. Bracts below or between flowers of reproductive short shoots 1 or 2 , entire or bifid, usually inconspicuous; spathellas (sac-like covers) around each floral bud are ovoid, with papillate surface; flowers along root margin, or sessile on upper root surface; flowers also along stems, arising from endogenous buds inside stem cortex; additional flowers on leaves (epiphyllous), arising from clefts of leaf forks; flower bud inside spathella completely inverted; flower in anthesis 1-1.5 mm; with pedicel ca. $2 \mathrm{~mm}$, curved at apex, at last erect, elongating to $4 \mathrm{~mm}$; tepals 2 and stamen 1 ; pollen released in monads, rarely dyads; ovary unilocular, lacking 

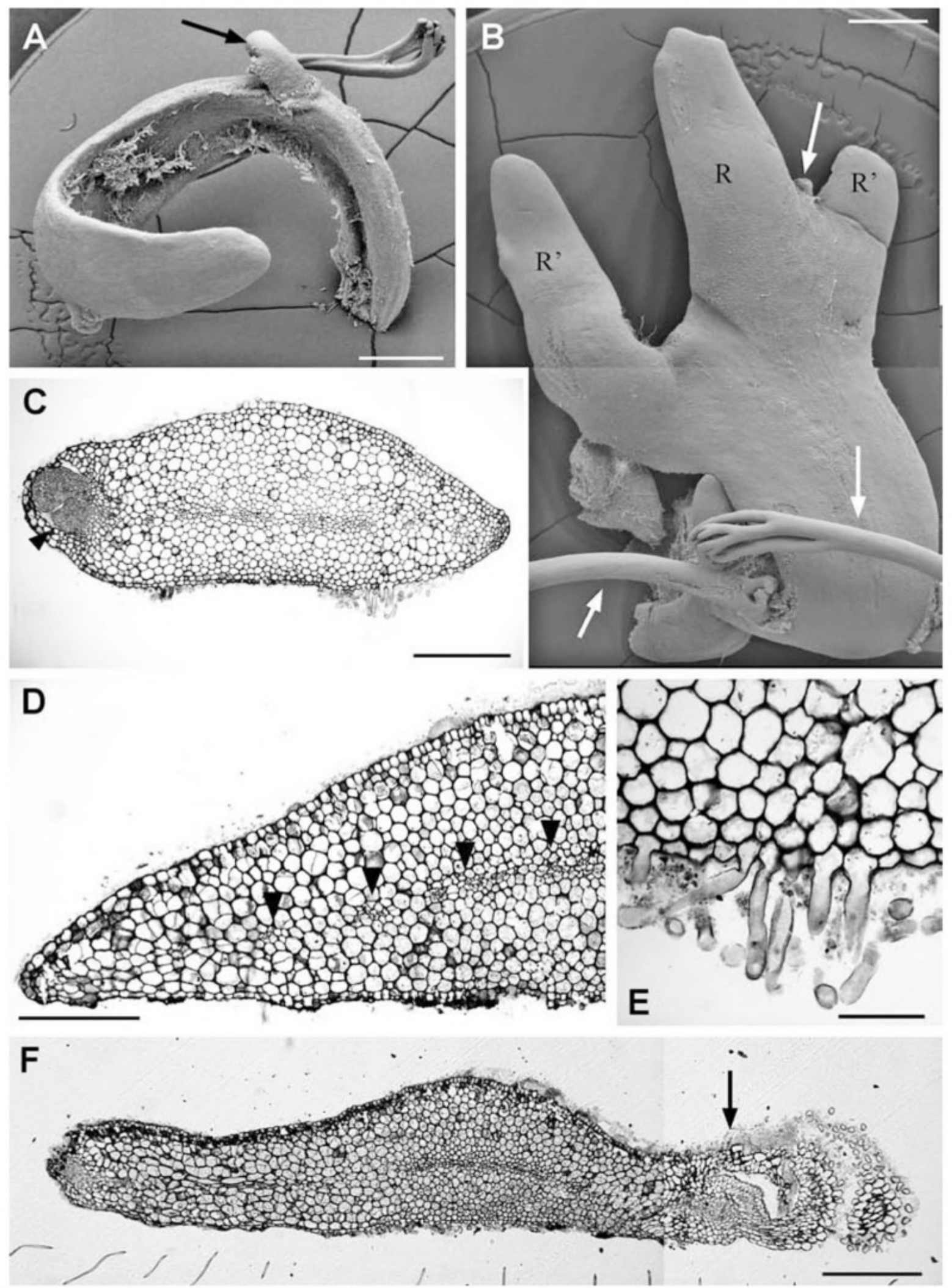

Figure 1. Stonesia ghoguei (from the type Ghogue GHO 1665). Roots and root-borne shoot buds. -A. Ribbon-like root twisted around stem base (see Fig. 6K). Arrow points to foliage leaf arising from endogenous site along root margin. Note adhesive hairs on flat lower root surface. Scale bar $=1 \mathrm{~mm} .-\mathrm{B}$. Distal portion of flattened root $(\mathrm{R})$ becoming crustose due to the outgrowth of exogenous lateral lobes $\left(\mathrm{R}^{\prime}\right)$. Arrows point to foliage leaves arising from endogenous sites along root margin. Scale bar $=1 \mathrm{~mm}$. - C. Cross section of ribbon-like root with young endogenous shoot bud (arrowhead). Note inconspicuous layer of vascular tissue inside root and adhesive hairs along lower surface. Scale bar $=500 \mu \mathrm{m}$. $-\mathrm{D}$. Cross section (left half) of another ribbon-like root. Arrowheads point to layer of vascular tissue. Scale bar $=250 \mu \mathrm{m}$. - E. Close-up of lower (ventral) root side with adhesive hairs. Scale bar $=100 \mu \mathrm{m}$. -F. Cross section of flattened crustose root. Arrow points to reproductive short shoot arising from root margin. Scale bar $=500 \mu \mathrm{m}$. 

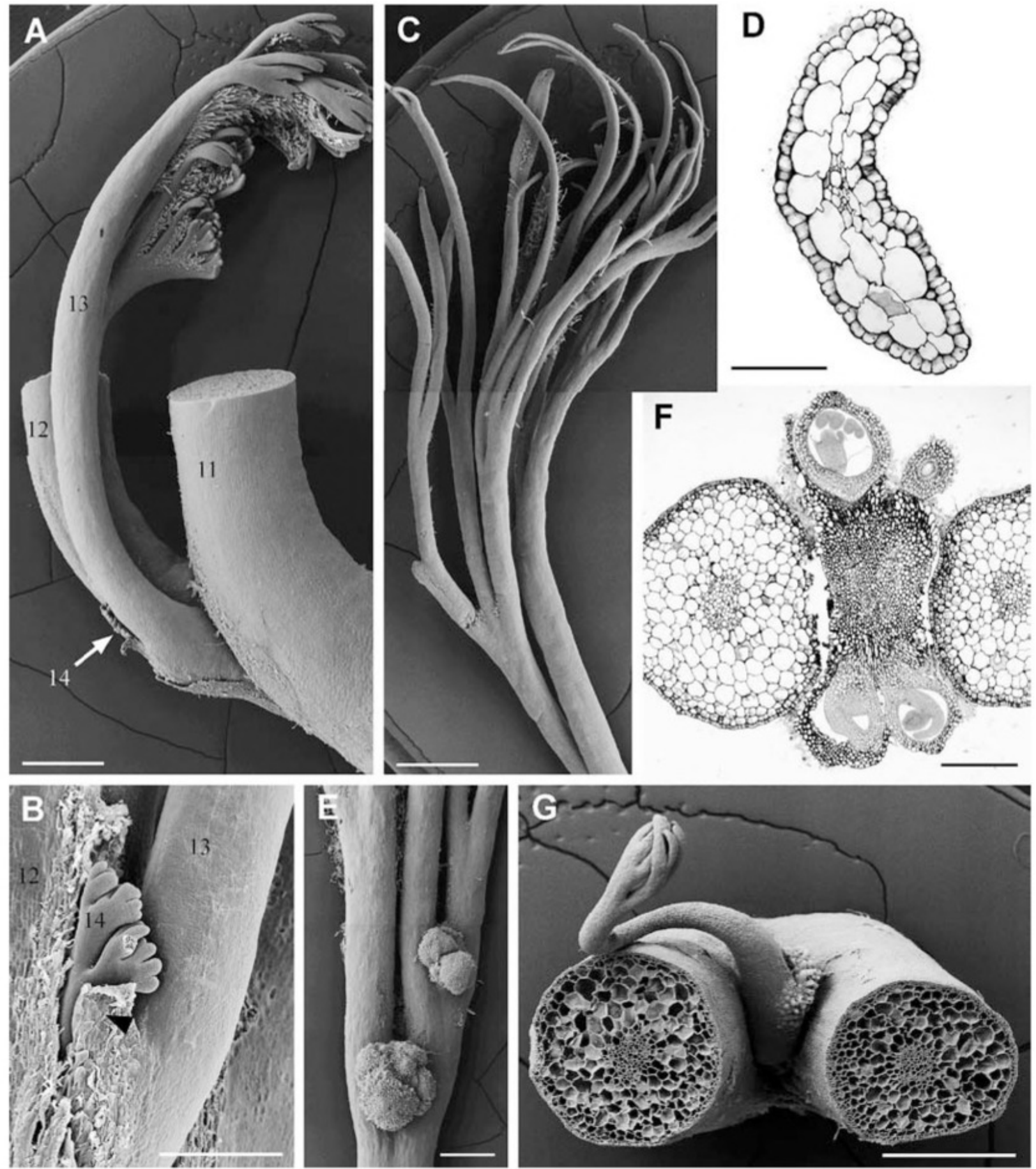

Figure 2. Stonesia ghoguei (from the type Ghogue GHO 1665). Leafy stems, compound leaves, and epiphyllous shoots. -A. Growing tip of vegetative shoot (as drawn in Fig. 6C, E), with two nearly mature leaves $(11,12)$ removed except for their petiole bases. Outgrowing leaf 13 with forked blade. Note hairs covering lower side of distal blade segments. Outgrowing young leaf 14 is observable on backside between 12 and 13 . Scale bar $=1 \mathrm{~mm} .-\mathrm{B}$. Close-up of young leaf 14 arising from pocket between 12 and 13. Arrowhead points to lateral stipule attached to leaf 13 . Scale bar $=500 \mu \mathrm{m}$. $-\mathrm{C}$. Distal portion of nearly mature compound blade. Few hairs along lower surface of distal leaf segments still present. Scale bar $=1 \mathrm{~mm} .-$ D. Cross section of distal leaf segment (flattened, with indistinct vascular bundle). Scale bar $=100 \mu \mathrm{m}$. -E. Proximal portion of compound blade, with two forks occupied by epiphyllous flower clusters. Scale bar $=1 \mathrm{~mm}$. -F. Cross section of proximal blade fork, its cleft occupied by an epiphyllous short shoot with four flower buds, surrounded by a spathella each. Scale bar $=500 \mu \mathrm{m}$. - G. SEM graph of another proximal blade fork, with epiphyllous leaf arising from cleft. Scale bar $=1 \mathrm{~mm}$. 

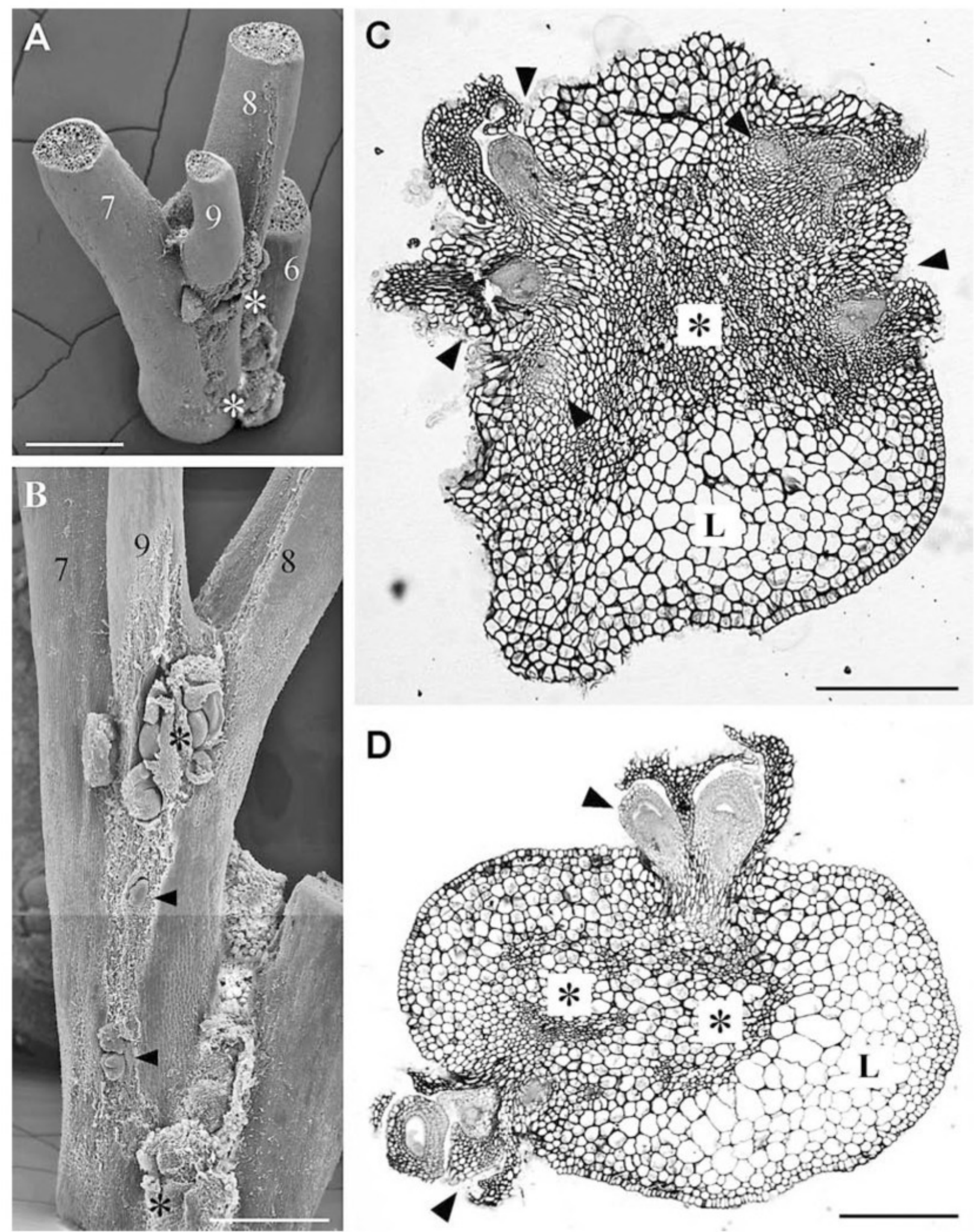

Figure 3. Stonesia ghoguei (from the type Ghogue GHO 1665). Mature stems with endogenous initiation of floral buds. -A, B. Two views of distal portion of $4.5 \mathrm{~cm}$ long stem (as drawn in Fig. 6L, M). Stem cortex ruptured due to endogenous formation of reproductive short shoots (asterisks). Arrowheads point to additional endogenous floral buds in between. Scale bars: $\mathrm{A}=$ $1 \mathrm{~mm} ; \mathrm{B}=500 \mu \mathrm{m}$. - C. Cross section of mature stem. $\mathrm{L}=$ stem sector exactly below insertion area of a foliage leaf, consisting of large parenchyma cells. Arrowheads point to sites in stem cortex with endogenous formation of floral buds. Note presence of scattered vascular tissue (asterisk) in stem center. Scale bar $=500 \mu \mathrm{m}$. - D. Cross section of another stem portion. Arrowheads point to floral buds with scale-like bracts rupturing the stem cortex. Asterisks indicate vascular tissue in stem center. Scale bar $=500 \mu \mathrm{m}$. 

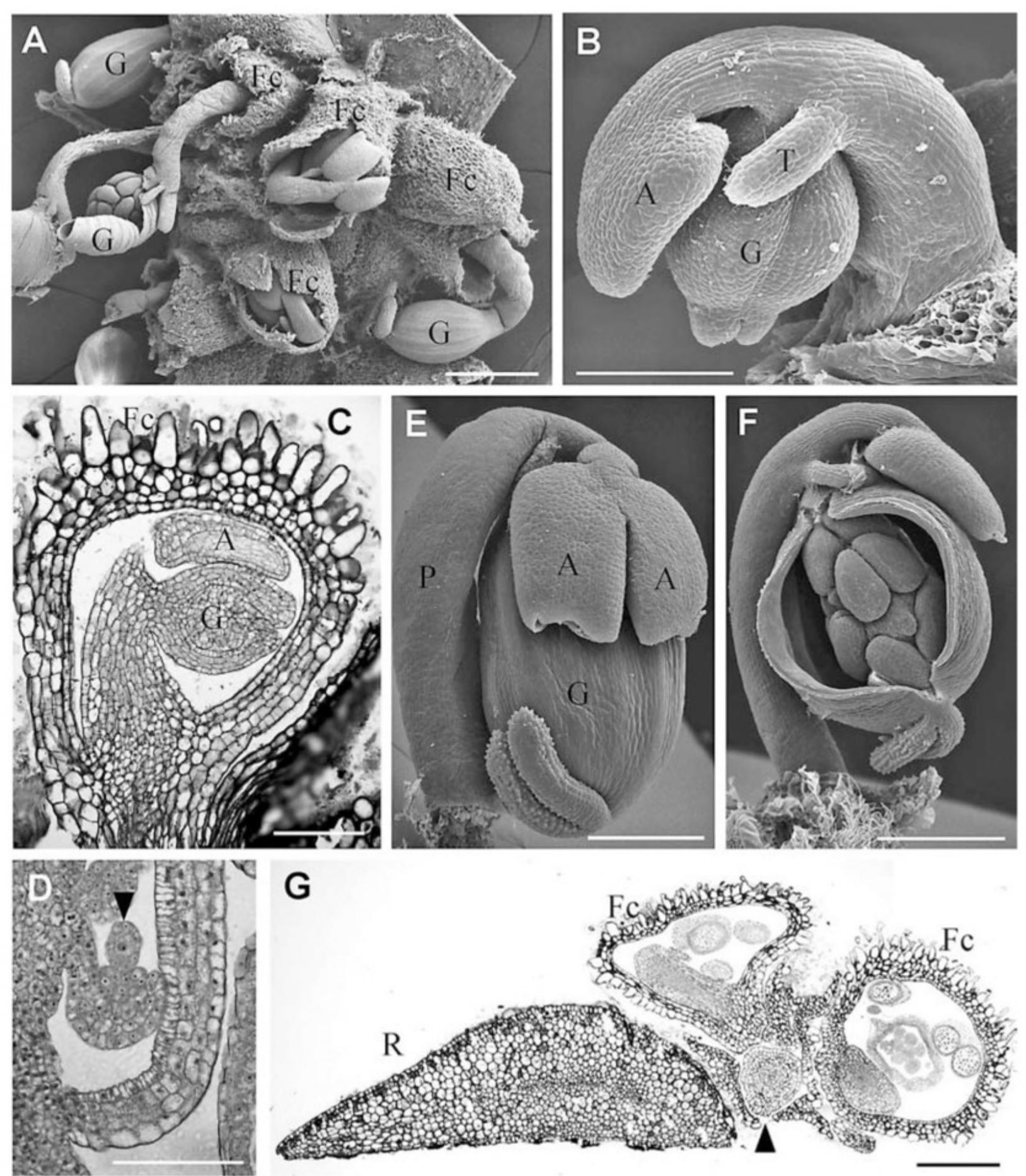

Figure 4. Stonesia ghoguei (from the type Ghogue GHO 1665). Reproductive structures, especially floral buds arising from stems and roots. - A. Cluster of floral buds on stem surface. Note presence of papillose spathellas (Fc), most of them ruptured in order to release anthers and gynoecia $(G)$. Scale bar $=1 \mathrm{~mm}$. - B. Strongly inclined floral bud (spathella removed), with young anther $(\mathrm{A})$, ovary $(\mathrm{G})$, and tepal $(\mathrm{T})$. Scale bar $=200 \mu \mathrm{m} .-\mathrm{C}$. Similar stage of strongly inclined floral bud inside spathella, with prominent papillae $(\mathrm{Fc})$. Abbreviations as above. Scale bar $=100 \mu \mathrm{m}$. $-\mathrm{D}$. Longitudinal section of young ovary, showing early stage of anatropous ovule, arising from central placenta. Note nucellar region (arrowhead) with megaspore cell projecting beyond the two primordial integuments. Scale bar $=100 \mu \mathrm{m}$. - E. Completely inverted floral bud on elongated pedicel $(\mathrm{P})$ prior to anthesis (spathella removed). Ovary $(\mathrm{G})$ with two linear stigma lobes. Note deep cleft between the two thecae (A). Scale bar $=400 \mu \mathrm{m}$. $-\mathrm{F}$. Another completely inverted floral bud (spathella removed). The ovary (young capsule) partly dehisced. Note central placenta with few ovules (immature seeds) and without septum. Scale bar $=500 \mu \mathrm{m} .-\mathrm{G}$. Cross section of ribbon-like root $(\mathrm{R})$ with short shoot consisting of two flowers in spathellas $(\mathrm{Fc})$. Arrowhead points to the "inflorescence axis," surrounded by scale-like bracts. Scale bar $=500 \mu \mathrm{m}$. 

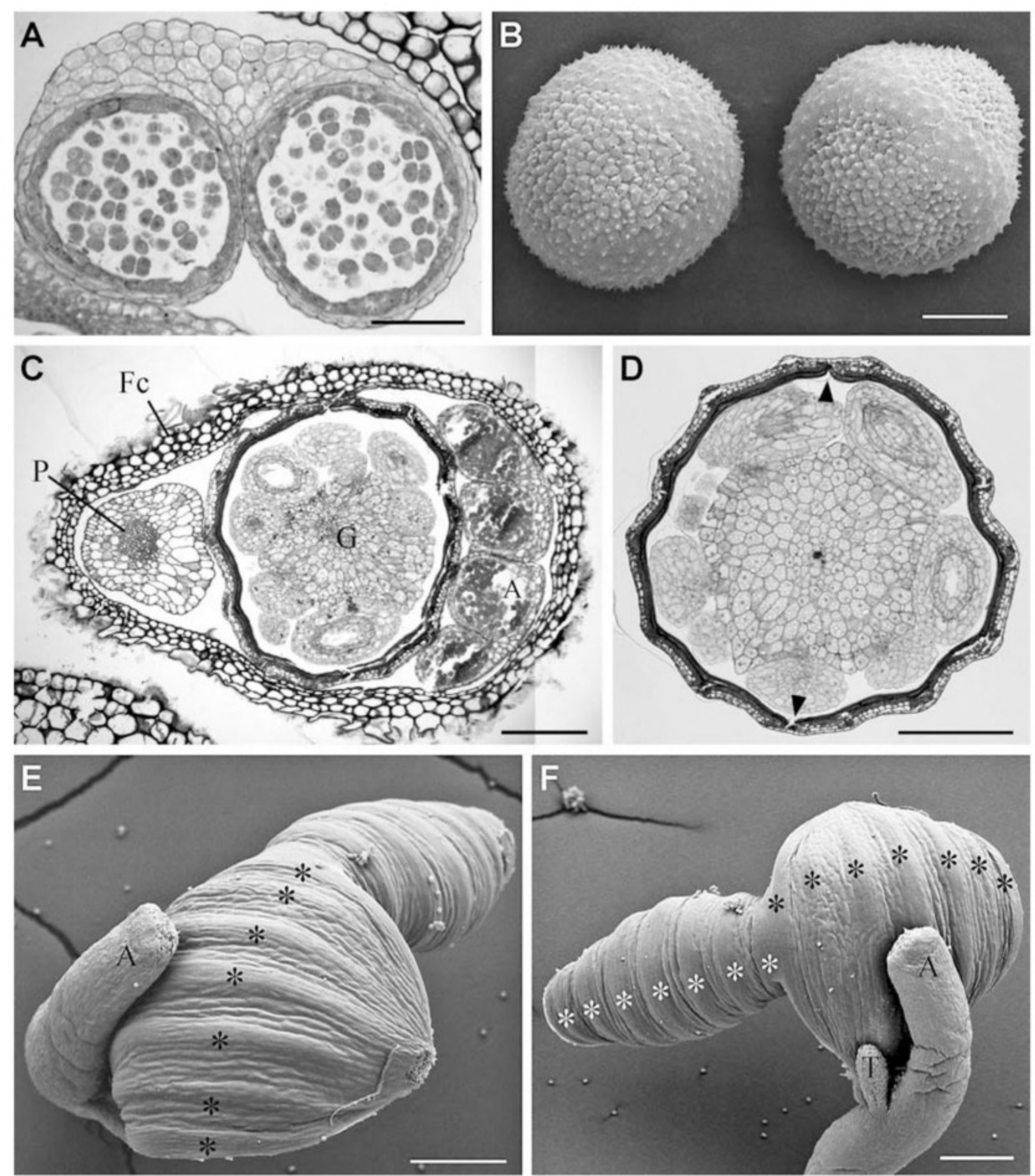

Figure 5. Stonesia ghoguei (from the type Ghogue GHO 1665). Reproductive structures such as stamen, pollen, ovary, and capsule. - A. Cross section of free theca tip with two pollen sacs. Immature pollen grains arranged in dyads and tetrads. Scale bar $=50 \mu \mathrm{m}$. - B. Two tricolpate pollen grains released as monads. Scale bar $=5 \mu \mathrm{m}$. - C. Cross section of anthetic flower prior to spathella ( $\mathrm{Fc}$ ) dehiscence. Note presence of pedicel $(\mathrm{P})$, unilocular ovary $(\mathrm{G})$ with 14 inconspicuous ribs, and anther with four introrse pollen sacs (A). Scale bar $=200 \mu \mathrm{m}$. -D. Nearly isolobous (immature) capsule, two valves with seven ribs each. Arrowheads point to the sutures along which the unilocular capsule will dehisce. Scale bar $=200 \mu \mathrm{m}$. $-\mathrm{E}, \mathrm{F}$. Two views of mature capsule, dehiscing into two nearly equal valves, each one with seven ribs. One valve stays attached to the base of the remaining floral parts $(\mathrm{A}=$ filament, $\mathrm{T}=$ tepal $)$. Scale bars $=250 \mu \mathrm{m}$.

septum, ellipsoidal, with 2 thread-like stigmas; capsule widely ellipsoid, valves 2 , equal or nearly so, ribs best observable when capsules mature; capsule valve with 5 or 7 ribs, ribs nearest the sutures shorter; seeds 15 to 20 per capsule.
Habitat and distribution. Stonesia ghoguei has been found in a strong waterfall on gneissic rock, on a $75^{\circ}-80^{\circ}$ slope. Due to the small population size, the very limited area of occupancy with just one location, and yet the lack of data on change in population size, 


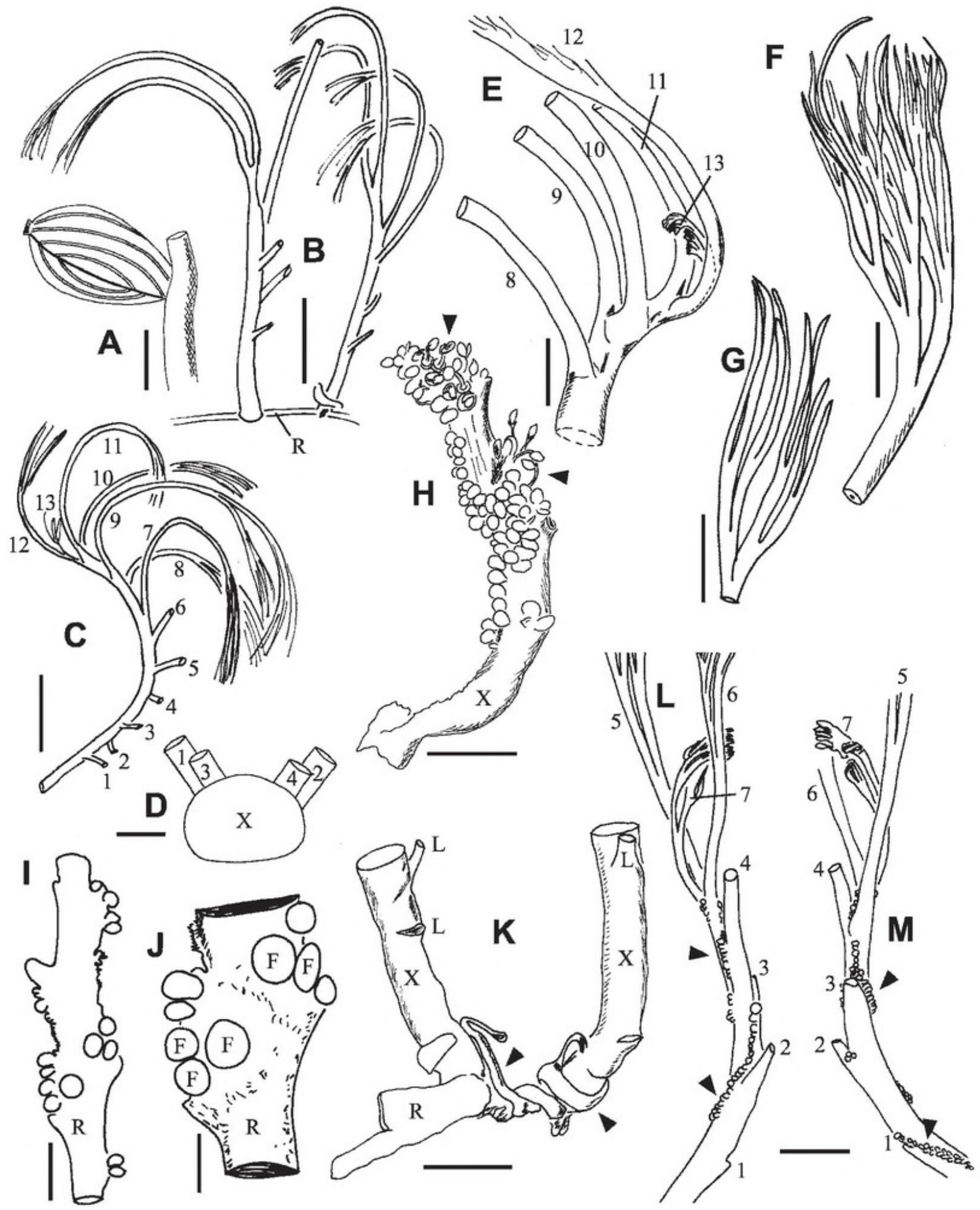

Figure 6. Stonesia ghoguei (from the type Ghogue GHO 1665: A-G, I-M; from the paratype Ghogue GHO 1668: H). -A. Nearly mature capsule with peculiar rib pattern as typical for Stonesia, Endocaulos, and Paleodicraeia. Scale bar $=0.5 \mathrm{~mm}$. - B. Two vegetative shoots arising from ribbon-like root $(\mathrm{R})$. Scale bar $=15 \mathrm{~mm}$. - C. Distal portion of elongate vegetative shoot, lower leaves ( 1 to 6 ) dropped, upper leaves ( 7 to 13 ) with repeatedly forked blade. Scale bar $=15 \mathrm{~mm}$. $-\mathrm{D}$. Scheme illustrating dorsiventral distichy of vegetative shoot, leading to secund leaf arrangement (1 to 4$)$ along stem $(\mathrm{X})$. Scale bar $=1 \mathrm{~mm}$. -E. Relative position of shoot tip shown in Figure 6C. Leaves 8 to 11 removed except for their petioles (see also Fig. 2A, B). Scale bar $=5 \mathrm{~mm}$. $-\mathrm{F}$. Nearly mature leaf with blade repeatedly forked. Scale bar $=5 \mathrm{~mm}$. $-\mathrm{G}$. Close-up of distal blade portion with three bifurcations. Scale bar $=5 \mathrm{~mm}$. $-\mathrm{H}$. Older stem portion (X,4 cm long), covered with many sessile flower buds; arrowheads point to spathellas that rupture to release flowers for anthesis. Scale bar $=5 \mathrm{~mm}$. - I, J. Portion of broad root ribbon $(\mathrm{R})$, seen from above, with sessile flower buds (F) along margins and on upper root surface. Scale bars $=3 \mathrm{~mm}$ and $1.5 \mathrm{~mm}$, respectively. $-\mathrm{K}$. Proximal portions of two root $(\mathrm{R})$-borne stems $(\mathrm{X})$, with basal leaves $(\mathrm{L})$ already dropped. Arrowheads point to outgrowth of young roots coiling around stem base (see close-up, Fig. 1A). Scale bar $=5 \mathrm{~mm}$. - L, M. Two opposite views of $4.5 \mathrm{~cm}$ long stem portion with proximal leaves ( 1 to 4 ) dropped and distal leaves (5 to 7 ) still present. Arrowheads point to emerging flower buds along oblique stem lines (see also close-ups in Fig. 3A, B). Scale bar $=10 \mathrm{~mm}$. 
we suggest the IUCN conservation status of Vulnerable (VU D1+2) (IUCN, 2001).

Etymology. The epithet of the new species honors the Cameroonian botanist Jean-Paul Ghogue (National Herbarium Yaoundé), who discovered this species in 2005.

Roots. Root architecture of Stonesia ghoguei is shown in Figures 1A-F, 6I-K. The roots are usually broad ribbons (to $5 \mathrm{~mm}$ broad), more rarely crustose structures resembling foliose lichens. Ribbons can turn into crusts by adding exogenous daughter lobes (Fig. 1B). Transverse sections show dorsiventrally flattened ribbons with a more or less planar lower surface fixed to the rock by adhesive hairs (Fig. 1C, E). The upper side of the ribbon contains some silica bodies, mainly in its hypodermis. The vascular tissue is a two-dimensional network of fine strands consisting of prosenchymatous cells, with phloem and xylem elements not distinguishable. Endogenous shoot buds and flowers originate from the root flanks (Fig. 1A, C, F), also from the sinus between two root lobes (Fig. 1B), and from the upper root surface (Fig. 6I, J). Additional roots grow out from the stem bases next to the mother root (Fig. 6K).

Vegetative shoots and leaves. Stem and leaf features of Stonesia ghoguei are shown in Figures $2 \mathrm{~A}-\mathrm{G}, 6 \mathrm{~B}-\mathrm{F}$. The leaves appear to be restricted to one stem sector with internode lengths of $1 \mathrm{~cm}$ or less (Fig. 6C, E). This secund leaf arrangement is a dorsiventral variant of distichous phyllotaxis (as illustrated in scheme Fig. 6D). Dorsiventral distichy results from repetitive leaf initiation from the backside of the so far youngest leaves (Fig. 2A, B). Leaves of older stem portions are coiled backward (Fig. 6C), whereas young leaves next to the shoot tip are straight (Fig. 2B). Young leaves have stipular lobes, which become inconspicuous later. Mature foliage leaves consist of wiry petioles, which carry laciniate blades resulting from repeated bifurcations (Figs. 2C, 6F, G). Distal blade segments are slightly flattened, with chloroplasts restricted to the smallcelled epidermis (Fig. 2D). Ultimate segments contain a weak vascular bundle each, whereas petioles and proximal segments are provided with a strong bundle each (Fig. 2F, G). No obvious phloem and xylem elements were detected in the leaves. The slightly concave side of young distal leaf segments are covered by hairs that soon wither and drop (Fig. 2A, C).

Position of flower buds. Flower buds (each covered with a sac-like spathella) arise along the root flanks and the upper root surface (Fig. 6I, J). These flowers are part of root-borne endogenous short shoots (Figs. 1C, F, 4G). Flower buds (solitary or in clusters) also arise along the stem without subtending leaves. Occasionally, there are hundreds of flowers covering a stem (Fig. 6H), or they are restricted to oblique stem lines, continuing the insertion zones of the leaves along the stem, with the stem sector just below leaf insertion not covered by flowers (Fig. 6L, M). The endogenous buds inside the stem cortex have the morphogenetic potential to create new floral buds ad infinitum or nearly so, intermingled with rudimentary scaly leaves (Fig. 3A-D). However, the rather largecelled tissue in the stem sector just below a leaf ( $\mathrm{L}$ in Fig. 3C, D) lacks this morphogenetical potential. The vascular tissue of mature stem portions consists of narrow cells (again, no obvious phloem and xylem), being compact (Fig. 3C) or arranged in a bow surrounding a parenchymatous pith (Fig. 3D). Flower buds were also observed on the leaves, arising from the clefts of proximal blade forks (Fig. 2E). There may be one or few floral buds per fork (Fig. 2F). Epiphyllous buds occasionally start with a small leaf prior to the outgrowth of flowers (Fig. 2G).

Spathellas as covers for flower buds. The sac-like spathella covering a flower bud is four to five cells thick (Figs. 2F, 3D). It lacks any vascular tissue and carries papillae except for the basal zone (Fig. 4C, G). Young flower buds are inclined, with the pedicel axis and the ovary axis forming angles of $45^{\circ}-90^{\circ}$ (Fig. 4B, C). Fully developed flowers are pedicellate and completely inverted inside the spathella, with the stigma facing the base (Figs. 4E, 5C). At anthesis, the spathella ruptures with irregular distal teeth (Fig. 4A).

Flowers and their parts. Flowering and fruiting in the natural habitat (Tello Waterfalls) reached a peak in February and March 2005, when the type and paratype (GHO 1665 and GHO 1668) were collected by J. P. Ghogue. The pedicel (floral stalk) continues to elongate as the spathella ruptures, pushing the young flower out of the broken spathella. The inverted stalked ovary and the single stamen assume an inclined to upright position (Figs. 4A, 6A). Each flower has two subulate (linear) tepals (Fig. 4B, F). The androecium consists of a single stamen with a prominent distal incision between the two thecae (Fig. 4E). Pollen sac dehiscence is introrse (Fig. 5C). The ovary is ellipsoidal, $1-1.5 \mathrm{~mm}$ long. There are two linear stigma lobes (Fig. 4E). The ovary is unilocular with free central placentation of 15 to 20 ovules, most of them becoming seeds (Figs. 4F, 5C, D). The mature ovules are anatropous, bitegmic, and tenuinucellate, with the nucellus exceeding the inner integument. This nucellar protuberance (containing the megaspore cell) is already observable in young ovules (Fig. 4D) when both integuments are still much shorter. Pollen grains during anthesis are mainly 
monads (Fig. 5B) besides few dyads, whereas immature anthers contain mainly dyads (Fig. 5A). Thus, it looks as if the dyads in this species fall apart quite easily. The pollen wall is slightly echinate and has three inconspicuous colpi (Fig. 5B).

Capsules. After anthesis, the flower stalks (pedicels) elongate up to $4 \mathrm{~mm}$; a gynophore is lacking (Figs. 5F, 6H). The pedicels initially consist of a sclerenchymatous central cylinder and a parenchymatous cortex (Fig. 5C). The capsule walls and the capsule stalks (pedicels) lose their parenchymatous cortex during the maturation process, as is typical for Podostemaceae. Thus, the rib pattern as already observable in anthetic ovaries becomes more prominent afterward. There are five to seven ribs per capsule valve plus the sutures, as is typical for Stonesia in general (Fig. 5C-F). The ribs nearest to the sutures do not run the whole capsule length, but begin on the suture above the base and, curving parallel to the other ribs, rejoin it below the apex (Fig. 6A). One (rarely both) of the equal valves is shed after capsule dehiscence. The capsules may split along one suture first, and later along the second one (Figs. 4A, F, 5F).

Molecular data. The aligned sequence length was 1542 bp. The selected optimal model of sequence evolution was the TVM $+\mathrm{G}$ model: unequal base frequencies $(\mathrm{A}=0.3320, \mathrm{C}=0.1467, \mathrm{G}=0.1263)$ and six substitution types (A/C: $1.3211, \mathrm{~A} / \mathrm{G}: 1.4110$, $\mathrm{A} / \mathrm{T}: 0.2497, \mathrm{C} / \mathrm{G}: 0.9004, \mathrm{C} / \mathrm{T}: 1.4110$ ), gamma distribution of rates among sites with alpha shape parameter 0.4785 . The analysis using these parameters yielded one optimal ML tree with a log-likelihood score of $-\operatorname{lnL}=4932.70$ (Fig. 7). The African podostemoid species included in the current analysis were monophyletic, with the two Madagascan genera Endocaulos and Thelethylax as sister. Ledermanniella subg. Phyllosoma C. Cusset (including L. ledermannii, $L$. cf. bosii) was paraphyletic to all other Podostemoideae studied from the African continent, including Dicraeanthus Engler, Dj̈nga C. Cusset, Stonesia, and four species belonging to Ledermanniella subg. Ledermanniella. The results shown in Figure 7 are identical to those presented by Moline et al. (2007) with respect to the set of non-African podostemoids.

Paratype. CAMEROON. Adamawa: Ngaoundéré, Tello Waterfalls, 10 Mar. 2005, J.-P. Ghogue GHO 1668 (K, YA, Z). Figure $6 \mathrm{H}$.

\section{DisCussion}

\section{MOLECULAR DATA}

Recently published molecular data indicate that there are two large groups among African Podoste- moideae (Kita et al., 2005; Moline et al., 2007). One is a grade composed of Ledermanniella subg. Phyllosoma, the other one is a clade composed of Ledermanniella subg. Ledermanniella and various small genera nested within, e.g., Dicraeanthus (two species, Cameroon) and Djinga (monotypic, Cameroon). In the present study, we show that GHO 1665 , which we regard as a new Cameroonian member of the genus Stonesia, is also nested in this large clade (Fig. 7), confirming the artificialness of the genus Ledermanniella, especially its subgenus Ledermanniella. The genus Stonesia is characterized by an increased number of capsule ribs and the ribs close to the sutures not reaching the base and tip of the capsule. This pattern is similar to Endocaulos and Paleodicraeia C. Cusset (both from Madagascar), but unlike all other Podostemoideae from Continental Africa. With the molecular data shown in Figure 7, the phylogenetic distance between Stonesia and Endocaulos becomes obvious, and we can confirm the peculiar pattern of capsule ribs they have in common as homoplasies. However, we should consider that the inclusion of additional genes and additional taxa may change the topology of the African podostemoids already studied. As shown above, there are no conclusive molecular data available at the moment, except for the view to merge genera such as Dicraeanthus, Djinga, and Stonesia into the large African genus Ledermanniella, which appears paraphyletic without them (Fig. 7). Alternatively, splitting the heterogenous Ledermanniella into monophyletic, morphologically uniform groups could be implemented when sufficient molecular data become available.

\section{HOW TO DEFINE GENERA IN AFRICAN PODOSTEMOIDEAE?}

As shown in Cook and Rutishauser (2007), a set of few easily recognizable features was enough to describe a new podostemaceous genus in earlier days, until the advent of molecular systematics. Podostemoid genera, which are not difficult to define morphologically, include in Africa Dicraeanthus, Djinga, and Stonesia. Djinga (one sp.) is recognizable because of globular smooth capsules (lacking ribs or nearly so), also by oblique flower buds inside the spathella (i.e., not being completely inverted as in typical Ledermanniella). Dicraeanthus and Stonesia (both with completely inverted flower buds) are recognizable by other characters not observable in Ledermanniella: Dicraeanthus showing elongate ovaries (capsules) with short conical stigma lobes; Stonesia showing an increased number of capsule ribs with the ribs close to the sutures not reaching the base and tip of the capsule. Thus, we prefer as a preliminary hypothesis to acknowledge the value of 


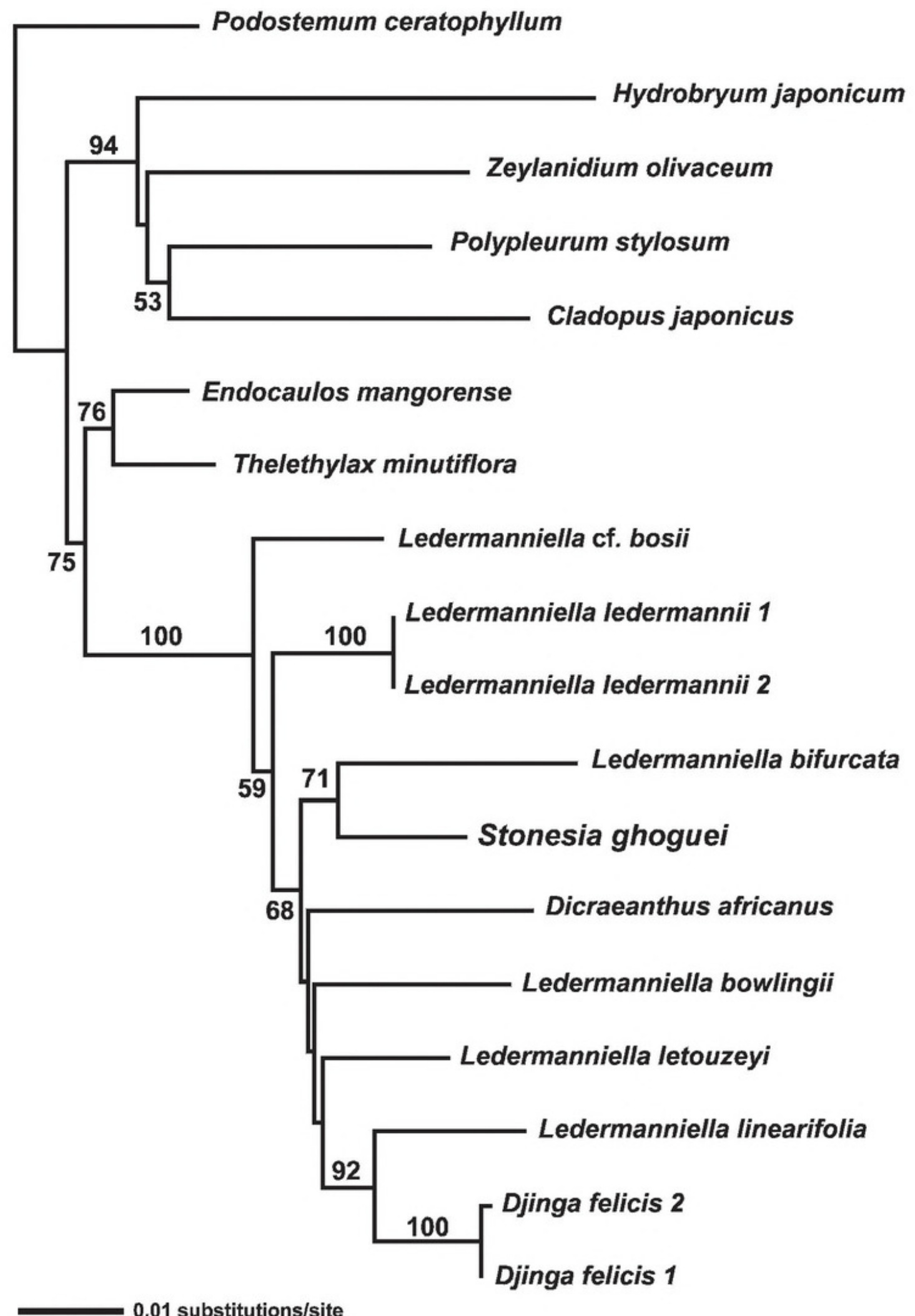

Figure 7. Maximum likelihood tree $(-\operatorname{lnL}=4932.70)$ of phylogenetic analysis of Podostemaceae-Podostemoideae from Continental Africa (species of Dicraeanthus, Djinga, Ledermanniella, Stonesia), Madagascar (Endocaulos, Thelethylax), Asia (Cladopus H. Möller, Polypleurum, Hydrobryum Endlicher, Zeylanidium), and America (Podostemum), based on matK sequence data (aligned sequence length $1542 \mathrm{bp}$ ). A modified data set by Moline et al. (2007) (tree base M2581) was used, and Stonesia ghoguei (GenBank Acc. No. AM937251) was added. A maximum likelihood (ML, Felsenstein, 1981) analysis was performed using PAUP 4.0. The analysis using these parameters yielded one optimal ML tree with a log-likelihood score of $-\operatorname{lnL}=4932.70$. Bootstrap support is indicated above branches. For further explanation, see text. 
crisp sets of morphological characters, which allow identification of podostemoid genera in the field, over monophyly (cf. Nordal \& Stedje, 2005). By keeping genera such as Dicraeanthus, Djinga, and Stonesia, these sets of characters have a label, which makes communication about African Podostemoideae easier. Moreover, we think it is best to describe $S$. ghoguei (GHO 1665 and GHO 1668) as a new Cameroonian species of the genus Stonesia. Further molecular studies, including the Stonesia members from Guinea and Sierra Leone, are needed to verify or falsify this mainly morphological approach to taxonomy. Unfortunately, the three western Stonesia species seem to be endangered too and are not readily available for comparative and molecular studies.

\section{STONESIA GHOGUEI AS A SOMEWHAT ABERRANT MEMBER OF} THE GENUS STONESIA

The genus Stonesia has capsule valves with five or seven ribs, the ribs nearest to the sutures are shorter than others and do not reach the ends of the valves. Unlike the western Stonesia species (from Guinea and Sierra Leone), S. ghoguei has pollen released mainly in monads (not dyads), one stamen per flower with two lateral tepals (not two stamens with three tepals), and moreover, $S$. ghoguei has unilocular ovaries, not bilocular ones as described for the western Stonesia species. Comments for these three seemingly deviating characters will be given below:

Monads versus dyads. Most podostemoids show tricolpate pollen (Cook \& Rutishauser, 2007). The pollen grains in the presumably basal New World genera such as Apinagia Tulasne, Marathrum Bonpland, and Mourera Aublet are shed in monads. In more derived podostemoids, including all Asian, all Madagascan, and many African taxa, they are shed in dyads (Cook \& Rutishauser, 2007). According to Jäger-Zürn et al. (2005), occurrence of monads in Podostemaceae appears to be correlated with simultaneous microsporogenesis, whereas dyads are mainly found in podostemoid taxa with successive microsporogenesis, e.g., Polypleurum (Tulasne) Warming and Zeylanidium Engler from southern Asia. The large African genus Ledermanniella shows both monads and dyads, depending on the species (Cusset, 1983, 1984, 1987). In Djinga (monotypic, Cameroon) and Stonesia (S. ghoguei), the dyads seem to decay easily into monads. Ghogue et al. (in prep.) found ca. $80 \%$ dyads and ca. $20 \%$ monads in nearly mature anthers of $D$. felicis. In $S$. ghoguei, most pollen grains leave the dehiscing anthers as monads. However, many dyads are still observable in the premature anthers (Fig. 5A,
B). In the three western Stonesia species, the released pollen are also described as dyads (Taylor, 1953; Cusset, 1973). Thus, it is best to accept the two character states "monads" versus "dyads" as less contrasting and exclusive as usually thought for the distinction of podostemoid genera (Cook \& Rutishauser, 2007).

One stamen versus two stamens per flower. Unlike Stonesia ghoguei, the flowers of the three western Stonesia species show two fused stamens on a common foot (called "andropodium") plus three subulate tepals, one tepal on each side of the andropodium, and the third tepal in the fork between the filaments. This character state also occurs in the Madagascan genus Thelethylax and the American genus Podostemum Michaux (Philbrick \& Novelo, 2004; Moline et al., 2006). In both genera (Podostemum, Thelethylax), there are known species or populations lacking the third median tepal (Grob et al., 2007). The switch from two stamens with andropodium to flowers with a single stamen may appear as crucial for species delimitation. However, both patterns can be found even within the same species. For example, flowers with two stamens (on a common andropodium) besides flowers with a single stamen are known in Letestuella tisserantii G. Taylor (western tropical Africa) and Oserya coulteriana Tulasne (Mexico), as already described by Warming (1899), Taylor (1953), Cusset (1980), and Novelo and Philbrick (1997).

Unilocular versus bilocular ovaries. The bicarpellate ovary of Podostemoideae can be either bilocular, with a prominent central placenta and a thin septum, or it can be unilocular lacking a septum, as found in Stonesia ghoguei. Bilocular ovaries represent the plesiomorphic condition in podostemoids, occurring in most non-African members, but in only a few African and Madagascan taxa such as Endocaulos, Sphaerothylax Bischoff ex C. Krauss, Thelethylax, and Saxicolella Engler p.p. (Jäger-Zürn, 2000; Ameka et al., 2002; Cook \& Rutishauser, 2007; Moline et al., 2007). Cusset (1973) described the three western Stonesia species as having bilocular ovaries. Taylor (1953) did not yet consider this character. We checked additional herbarium material of S. fascicularis G. Taylor and S. heterospathella G. Taylor in Z/ZT, confirming the presence of a septum. Thus, both unilocular and bilocular ovaries are found as character states in Stonesia. Here we have to keep in mind that unilocular ovaries also have a rudimentary septum in the basal ovary region, as observable in Djinga felicis (Ghogue et al., in prep.) and Ledermanniella bowlingii (Ameka et al., 2003). 
COMPARISON OF STONESIA GHOGUEI WITH OTHER AFRICAN AND MADAGASCAN PODOSTEMOIDS

Various characters of Stonesia (including $S$. ghoguei) are found in some or a few other African podostemoids. Comments are given below regarding six characters:

Flower buds are inverted in spathella. The inverted flower in the unruptured spathella is a synapomorphy of various African and Madagascan members (including Stonesia), whereas an upright (erect) flower in the unruptured spathella is plesiomorphic (Moline et al., 2007). African podostemoids such as Stonesia have completely inverted flowers inside fully developed spathellas, even though they start with inclined ovaries in early developmental stages. They become inverted by pedicel elongation inside the growing spathella (Fig. 4B, C). The Madagascan podostemoids with an increased number of capsule ribs (similar to Stonesia) are Endocaulos and Paleodicraeia. The two latter genera, however, show erect or only slightly inclined flower buds inside the spathella (Cook \& Rutishauser, 2007; Grob et al., 2007).

Crustose roots or broad ribbons have exogenous daughter roots covering the rocky substrate. The three Stonesia species from Guinea and Sierra Leone (i.e., the western Stonesia species) are described as having crustose roots, whereas, for example, the roots of other African genera and the Madagascan Paleodicraeia and Thelethylax are narrow to broad ribbons, with the root cap absent or present (Ameka et al., 2002; Rutishauser \& Moline, 2005; Koi et al., 2006; Moline et al., 2007; Rutishauser et al., 2008). Stonesia ghoguei behaves somewhat intermediate by producing ribbons that can turn into crusts by adding broad lateral lobes (daughter roots) that arise exogenously from the mother root (Fig. 1A-F). Stonesia ghoguei roots lack a cap, similar to the western Stonesia species.

Stems are usually simple, up to $10 \mathrm{~cm}$ long in Stonesia ghoguei. Prominent and rather thick stems (monopodial, rarely branched) are also found in the western Stonesia species. In S. fascicularis the stems can be up to $40 \mathrm{~cm}$ long, whereas $S$. heterospathella and $S$. taylorii C. Cusset have stem lengths around $10 \mathrm{~cm}$, i.e., similar to $S$. ghoguei (Taylor, 1953; Cusset, 1973). Simple or rarely branched stems of 10 $30 \mathrm{~cm}$ lengths are also known from Dicraeanthus africanus and Ledermanniella letouzeyi (Moline et al., 2007). We could not observe double-sheathed leaves in S. ghoguei. These are leaves with two sheaths that are inserted laterally and opposite each other. Doublesheathed leaves occur in many podostemoids with elongate stems that are branched (Moline et al., 2006, 2007).

Cauliflory is due to endogenous origin of flower buds inside the stem cortex. Stonesia ghoguei has plenty of sessile flower buds covering the stem surface and not being subtended by leaves. These flowers arise from endogenous buds inside the stem cortex, they protrude the stem periphery, rupturing the outer cortex layers and the epidermis (Fig. 3C, D). Similarly, Dicraeanthus africanus, Ledermanniella letouzeyi, and Macropodiella heteromorpha (Baillon) C. Cusset are able to produce hundreds of flowers from endogenous buds formed inside the stem cortex (Rutishauser \& Moline, 2005; Cook \& Rutishauser, 2007; Moline et al., 2007; Rutishauser et al., 2007; Pfeifer et al., unpublished data). The drawings of M. Stones (published in Taylor, 1953) show a similar floral arrangement (i.e., cauliflory) in the western Stonesia species, especially in S. fascicularis. Because Stones and Taylor did not present microtome sections, we only can assume that cauliflory in $S$. fascicularis is also due to endogenous bud inception inside the stem cortex. Stonesia taylorii (described as additional Guinean species by Cusset, 1973) carries either rudimentary or well-developed flowers along two stem sectors.

Leaves are repeatedly forked into narrow segments, with epiphyllous flowers arising from the clefts of the forks. Stonesia ghoguei is peculiar by carrying additional flowers on the leaves. There are up to 15 epiphyllous flowers arising from each of the proximal clefts of the repeatedly forked blade (Fig. 2E-G). Epiphyllous flowers are also known from two Cameroonian Ledermanniella species: L. letouzeyi and L. prasina J. J. Schenk \& D. W. Thomas (Schenk \& Thomas, 2004; Rutishauser \& Moline, 2005; Moline et al., 2007). The drawings by M. Stones (published in Taylor, 1953) show similar patterns in the western Stonesia species, especially in S. heterospathella.

There are few scale-like leaves (bracts) below each spathella. The three western Stonesia species are distinguishable from each other by the shape of the bracts of the reproductive short shoots. Stonesia taylorii (as described by Cusset, 1973) is characterized by two to six trifid or quadrifid bracts per oneflowered short shoot, whereas in the two other western Stonesia species the few bracts below each spathella are entire or inconspicuous. Similarly, the bracts accompanying the few-flowered short shoots in $S$. ghoguei are usually entire and only rarely lobed (Figs. 3C, D, 4G). Two types of spathellas, as described by Taylor (1953) in S. heterospathella, were not observed in S. ghoguei. 


\section{Conclusions}

The developmental and morphological studies of the Cameroonian specimens collected by J. P. Ghogue (GHO 1665 \& GHO 1668) indicate that it is best to describe them as a new species, belonging to Stonesia, mainly due to the presence of the very peculiar pattern of capsule ribs. The similar rib pattern in Madagascan genera (Endocaulos, Paleodicraeia) evolved independently in a clade also comprising Thelethylax (Grob et al., 2007; Thiv et al., in prep.).

Acknowledgements. Many thanks to Jean-Paul Ghogue (National Herbarium Yaoundé, Cameroon), the discoverer of the new Stonesia species. We are grateful for valuable comments from G. Ameka (Legon, Ghana) and K. Huber (Zurich) on draft versions of this manuscript. P. Endress (Zurich) and Roy Gereau helped in translating the species diagnosis into Latin. Technical assistance with scanning electron microscopy of U. Jauch (Institute of Plant Biology, University of Zurich) is acknowledged. This paper is part of a research project supported by the Swiss National Science Foundation (grant No. 3100AO-105974) to R. Rutishauser.

\section{Literature Cited}

Ameka, G. K., E. Pfeifer \& R. Rutishauser. 2002. Developmental morphology of Saxicolella amicorum and S. submersa (Podostemaceae: Podostemoideae) from Ghana. Bot. J. Linn. Soc. 139: 255-273.

_, C. G. Clerk, E. Pfeifer \& R. Rutishauser. 2003. Developmental morphology of Ledermanniella bowlingii (Podostemaceae) from Ghana. Pl. Syst. Evol. 237: 165-183.

Cook, C. D. K. 1999. The number and kinds of embryobearing plants, which have become aquatic: A survey. Perspect. Pl. Ecol. Evol. Syst. 2: 79-102.

\& R. Rutishauser. 2007. Podostemaceae. Pp. 304-344 in K. Kubitzki (editor), The Families and Genera of Vascular Plants, Vol. 9. Springer, Berlin.

Cusset, C. 1973. Contribution à l'étude des Podostemaceae. III. Le genre Stonesia. Adansonia, Sér. 2 13: 307-312.

. 1974. Contribution à l'étude des Podostemaceae. IV. Les genres Ledermanniella, Monandriella et Inversodicraeia. Adansonia, Sér. 2 14: 271-275.

1980. Contribution à l'étude des Podostemaceae. 6. Les genres Leiothylax, et Letestuella. Adansonia, Sér. 2 20: 199-209.

—_. 1983 [1984]. Contribution à l'étude des Podostemaceae. 7. Ledermanniella Engl. sous-genre Phyllosoma C. Cusset. Bull. Mus. Natl. Hist. Nat., B, Adansonia 4: 361-390. —. 1984. Contribution à l'étude des Podostemaceae. 8. Ledermanniella Engl. sous-genre Ledermanniella. Bull. Mus. Natl. Hist. Nat., B, Adansonia 3: 249-278.

1987. Podostemaceae and Tristichaceae. Flore du Cameroun 30: 51-99.

Engler, A. 1928. Reihe Podostemales. Pp. 1-68, 483-484 in A. Engler \& K. Prantl (editors), Die natürlichen Pflanzenfamilien, 2nd ed. Duncker \& Humblot, Berlin [published as volume in 1930].
Felsenstein, J. 1981. Evolutionary trees from DNA sequences: A maximum likelihood approach. J. Molec. Evol. 17: $368-376$.

Grob, V., E. Pfeifer \& R. Rutishauser. 2007. Morphology, development and regeneration of Thelethylax minutiflora, a Madagascan riverweed (Podostemaceae). Phyton 47: 205-229.

IUCN. 2001. IUCN Red List Categories and Criteria, Version 3.1. Prepared by the IUCN Species Survival Commission. IUCN, Gland, Switzerland, and Cambridge, United Kingdom.

Jäger-Zürn, I. 2000. The unusual ramification mode of Sphaerothylax abyssinica (Wedd.) Warm. (Podostemaceae-Podostemoideae). Flora 195: 200-227.

- A. R. Novelo \& C. T. Philbrick. 2005. Microspore development in Podostemaceae-Podostemoideae, with implications on the characterization of the subfamilies. Pl. Syst. Evol. 256: 209-216.

Kato, M. 2006. Distribution and biogeography of Podostemaceae in Asia. Bull. Natl. Sci. Mus., Tokyo, B. 32: $19-27$.

Kita, Y., R. Imaichi, J.-P. Ghogue, G. K. Ameka \& M. Kato. 2005. Molecular phylogeny of Cameroonian and Ghanaian Podostemaceae. Abstract Poster, International Botanical Congress, Vienna.

Koi, S., R. Fujinami, N. Kubo, I. Tsukamoto, R. Inagawa, R. Imaichi \& M. Kato. 2006. Comparative anatomy of root meristem and root cap in some species of Podostemaceae and the evolution of root dorsiventrality. Amer. J. Bot. 93: 682-692.

Lebrun, J. P. \& A. L. Stork. 1991. Enumeration des plantes à fleurs d'Afrique tropicale. 1. Généralités et Annonaceae à Pandaceae. Conservatoire et Jardin botaniques de Genève, Genève.

Moline, P. M., L. Don, C. T. Philbrick, R. A. Novelo, E. Pfeifer \& R. Rutishauser. 2006. Comparative morphology and molecular systematics of Podostemum (including Crenias)—American River-weeds (Podostemaceae). Bot. Jahrb. Syst. 126: 427-476.

M. Thiv, G. K. Ameka, J.-P. Ghogue, E. Pfeifer \& R. Rutishauser. 2007. Comparative morphology and molecular systematics of African Podostemaceae-Podostemoideae, with emphasis on Dicraeanthus and Ledermanniella from Cameroon. Int. J. Pl. Sci. 168: 159-180.

Nordal, I. \& B. Stedje. 2005. Paraphyletic taxa should be accepted. Taxon 54: 5-6.

Novelo, R. A. \& C. T. Philbrick. 1997. Taxonomy of Mexican Podostemaceae. Aquatic Bot. 57: 183-200.

Philbrick, C. T. \& R. A. Novelo. 2004. Monograph of Podostemum (Podostemaceae). Syst. Bot. Monogr. 70: 1-106.

Posada, D. \& K. A. Crandall. 1998. Modeltest: Testing the model of DNA substitution. Bioinformatics 14: 817-818.

Rutishauser, R. \& P. M. Moline. 2005. Evo-devo and the search for "sameness" in biological systems. Theor. Biosci. 124: 213-241.

E. Pfeifer \& A. Bernhard. 2007. Podostemaceae of Africa and Madagascar: Keys to genera and species, including genera descriptions, illustrations to all species known, synonyms, and literature list. Version 20-07-2007. Available at: <http://www.systbot.uzh.ch/podostemaceae>, accessed 12 December 2008.

_, V. Grob \& E. Pfeifer. 2008. Plants are used to having identity crises. Pp. 194-213 in A. Minelli \& G. Fusco (editors), Evolving Pathways: Key Themes in Evolutionary Developmental Biology. Cambridge University Press, Cambridge. 
Schenk, J. J. \& D. W. Thomas. 2004. A new species of Ledermanniella (Podostemaceae) from Cameroon. Novon 14: 227-232.

Swofford, D. L. 1998. PAUP* 4.0: Phylogenetic Analysis Using Parsimony (*and other methods). Sinauer Associates, Sunderland, Massachusetts.
Taylor, G. 1953. Notes on Podostemaceae for the revision of the Flora of West Tropical Africa. Bull. Brit. Mus. (Nat. Hist.), Bot. 1: 53-79.

Warming, E. 1899. Familien Podostemaceae V. Kongel. Danske Vidensk. Selsk. Naturvidensk. Math. Afd. 9: 105-154. 


\section{$2 \mathrm{BHL}$ Biodiversity Heritage Library}

Pfeifer, Evelin et al. 2009. "Stonesia ghoguei, Peculiar Morphology of a New Cameroonian Species (Podostemaceae, Podostemoideae)." Novon a journal of botanical nomenclature from the Missouri Botanical Garden 19, 102-116.

View This Item Online: https://www.biodiversitylibrary.org/item/124658

Permalink: https://www.biodiversitylibrary.org/partpdf/121885

\section{Holding Institution}

Missouri Botanical Garden, Peter H. Raven Library

\section{Sponsored by}

Missouri Botanical Garden

\section{Copyright \& Reuse}

Copyright Status: Permission to digitize granted by rights holder Rights: https://www.biodiversitylibrary.org/permissions

This document was created from content at the Biodiversity Heritage Library, the world's largest open access digital library for biodiversity literature and archives. Visit BHL at https://www.biodiversitylibrary.org. 